\title{
EFFECT OF HIGH TEMPERATURE SHOCK ON SURVIVAL OF THE GRAIN MITE TYROPHAGUS PUTRESCENTIAE (SHRANK) (ACARI : ACARIDIDA)
}

\author{
MARIAM A. EL-SANADY \\ Plant Protection Research Institute, ARC, Dokki, Giza \\ (Manuscript received 3 March 2009)
}

\begin{abstract}
Heating is used extensively to control some pests as well as stored-product pests. There are three temperature zones for any organisms: optimal at $25-33^{\circ} \mathrm{C}$ for is greatest rate of growth and reproduction, suboptimal at $33-35^{\circ} \mathrm{C}$, mites able to complete their development slowly and produce offspring and Lethal $>35^{\circ} \mathrm{C}$ eventually die, The more extreme of temperature the more quickly die with death occurring in few minutes at $45^{\circ} \mathrm{C}$ or hours at 50 $60^{\circ} \mathrm{C}$.

Lethal effect of high temperature $\left(40,45 \& 50{ }^{\circ} \mathrm{C}\right)$ for different exposure periods $(5,15,30,60,90 \& 120 \mathrm{~min}$.), respectively, on survival stages of Tyrophagus putrescentiae (Shrank) was studied. Heat shock treatment reduced the number of all stages. The mean of mortality percentage increased with increasing temperature and duration. These percentage were $83,87 \& 92 \%$ for egg, 81.8, $86.2 \& 91.7 \%$ for larva, $71.3,82.2 \& 88.7 \%$ for protonymph and $70.3,81.5 \& 86 \%$ for deuotonymph at $40,45 \& 50^{\circ} \mathrm{C}$, respectively. it is notice thus mortality increased by increasing temperature and long time. Therefore all stages of the grain mite $T$. putrescentiae die at $50^{\circ} \mathrm{C}$ and $60 \mathrm{~min}$ exposure. At $45^{\circ} \mathrm{C}$ high mortality percentages occurred between mite individuals at $90 \mathrm{~min}$. while treatments at $40^{\circ} \mathrm{C}$ and $120 \mathrm{~min}$. exposure gave similar mortality percentage.
\end{abstract}

\section{INTRODUCTION}

The Acari includes a large economic group of arthropods (especially those of Acaridida) which are found commonly in stored products, where they cause injury by feeding and creating, in many instances, difficult contamination problems. For many years chemical measures have dominated the methods for pest control in grain, but recently more interest has been directed towards non-chemical methods. Such methods are needed because all major species of stored product pests have developed varying degrees of resistance to the limited number of pesticides which are internationally accepted for use on grain (Champ and Dyte, 1976). At the same time, new chemicals that are safe enough for use on foodstuffs are only slowly becoming available, because of high cost of developing and registering as "residue free" The experiment that has been successful for many years against stored product pests is the use of elevated temperatures. Heat shock is the form of stress caused by rapid 
exposure to high temperatures. Chen et al., 1991), and Waddell et al., (1993) determined the thermal death point for adult female Tetranychus urticae after heat temperature in water vapor air. (However, studies, on the impact of short exposure periods of high temperatures on the biology of $T$. urticae have not previously been carried out). The thermal limits of insects and mites usually fall between 0 and $50^{\circ} \mathrm{C}$ and temperatures within these limits determine the rates of population growth. More extreme temperatures have an acute influence. At upper limit, the high temperatures destabilize phospholipids membranes and affect intracellular proteins adversely (Bligh et al.,1976). Heat disinfestations requires only that all particles of a given batch of infested grain are heated to an appropriate lethal temperature/combination and this is basically a simple process. It can be adapted to both "low tech and high tech" circumstances (Kitch et al., 1992). Different mite and insect species and stages have different susceptibilities to heat treatment, but most species will not survive more than $12 \mathrm{~h}$ at $45^{\circ} \mathrm{C}, 5 \mathrm{~min}$. at $50^{\circ} \mathrm{C}$ and $30 \mathrm{~s}$. at $60^{\circ} \mathrm{C}$ (Fields, 1992). Mortality is obviously related to the temperature to which the pests are exposed and the exposure period. $\mathrm{A}$ heating block system was developed at Washington State University (WSU), Pullman, WA that provides accurate heating rates and temperature control in treating different insects. This system was used to study the thermal death kinetics of fifth instars codling moth (Ikediala et al., 2000, Wang et al., 2004), thermal of different life stages insect (Johnson et al. , 2003), and fifth instars navel orange worm. The same system was also used to determine the most heat resistant life stage of navel orange worms for developing thermal treatment protocols against field pests in shell walnuts (Wang et al., 2002c).

The present work aims to study the effect of high temperature stress (40, 45 \& $\left.50^{\circ} \mathrm{C}\right)$ with different exposure times $(5,15,30,60,90 \& 120 \mathrm{~min}$.) on survival stages of Tyrophagus puterscntiae (Sharank)

\section{MATERIALS AND METHODS}

\section{Pure culture}

A pure culture of the grain mite $T$. puterscntiae (Sharank) belonging to the family : Acaridae, was prepared by confining adult females and males in a rearing plastic chamber $(5.5 \mathrm{~cm}$ diameter $\times 1.5 \mathrm{~cm}$ high) filled up to $0.5 \mathrm{~cm}$. with plaster of Paris and activated charcoal (8:1). One adult female and male of the mite were placed in a plastic cell, supplied with dray yeast and a few drops of water added daily as a source of relative humidity. The cultures were observed daily and kept in an incubator at $25^{\circ} \mathrm{C} \pm 2$ and $60 \pm 5 \%$ R.H. 


\section{Eggs}

Assessment of reduction measured after exposing eggs to three high temperatures 40,45 and $50^{\circ} \mathrm{C}$ for various short exposure period. They were then reared on $25^{\circ} \mathrm{C}$ as the control temperature. Ten replicates were taken for each temperature and the surviving eggs were examined daily unit all eggs were dead.

\section{Immature stages}

Ten molted active immature stages (larva, protonymph and deutonymph) were placed in the rearing plastic chamber and distributed among three incubators of 40 , 45 and $50^{\circ} \mathrm{C}$ for various exposure periods $5,15,30,60,90$ and 120 min, respectively. Ten replicates for each treatment were used. The surviving mites were kept at $25^{\circ} \mathrm{C}$ and examined daily. Assessment mortality of larva, protonymph and deutonymph and also the percentage of survival were measured.

\section{RESULTS AND DISCUSSION}

Data in Table (1) indicated that the mean percentage mortality for $T$. puterscntiae eggs after shock exposure $(5,15,30,60,90 \& 120$ min.) at high temperatures $\left(40,45,50^{\circ} \mathrm{C}\right)$ significantly increased with increasing the degree of temperature. The mean percentage of egg mortality was represented by $92 \%$ at highest degree $50^{\circ} \mathrm{C}$ also recorded 100 with short exposure $30 \mathrm{~min}$, the mean significantly and gradually decreased at $45^{\circ} \mathrm{C}$ and recorded reduction $100 \%$ at 90 min, while at $40^{\circ} \mathrm{C} 83 \%$, recording 100 at 120 min The interaction effect of high temperatures with short exposure period was highly significant.

Table 1. Percentage of mortality for Tyrophagus putrescentiae eggs after different shock exposure at high temperatures.

\begin{tabular}{|c|c|c|c|c|}
\hline \multirow{2}{*}{$\begin{array}{c}\text { Exposure } \\
\text { period min. }\end{array}$} & \multicolumn{3}{|c|}{ High degree of temperatures } \\
\cline { 2 - 6 } & $40^{\circ} \mathrm{C}$ & $45^{\circ} \mathrm{C}$ & $50^{\circ} \mathrm{C}$ \\
\hline 5 & 65 & 71 & 85 \\
\hline 15 & 76 & 81 & 90 \\
\hline 30 & 82 & 85 & 100 \\
\hline 60 & 86 & 92 & 0 & $\begin{array}{c}\text { Fig (1) The precentage mortilty of eggs aftre } \\
\text { different short exposure to high temperatures. }\end{array}$ \\
\hline 120 & 89 & 100 & 0 & $92 \%$ \\
\hline Mean & $83 \%$ & $87 \%$ & 0 \\
\hline
\end{tabular}


The obtained results in table (2) cleared that the high temperature was more effective in reducing the mite larval stage. The mean percentage mites mortality treated by high temperature at the three tested degree with six exposure periods were significantly the mortality. However, the mean mortality percentages, then gradually and insignificantly increased to $(81.8,86.2 \& 91.7 \%)$ for increased of degree to $\left(40,45 \& 50^{\circ} \mathrm{C}\right)$ for above mentioned exposure periods, respectively. It also recorded $100 \%$ with short exposure $30 \mathrm{~min}$, then for degree $45^{\circ} \mathrm{C}$ recorded reduction 100 at $90 \mathrm{~min}$, while degree $40^{\circ} \mathrm{C}$ recorded $95 \%$ at $120 \mathrm{~min}$ The interaction effect of highly temperatures with short exposure period was high significant.

Table 2. Percentage of mortality stage Tyrophagus putrescentiae larvae after different shock exposure at high temperatures.

\begin{tabular}{|c|c|c|c|}
\hline \multirow{2}{*}{$\begin{array}{c}\text { Exposure } \\
\text { period } \\
\text { min. }\end{array}$} & \multicolumn{3}{|c|}{ High degree of temperatures } \\
\cline { 2 - 4 } & $40^{\circ} \mathrm{C}$ & $45^{\circ} \mathrm{C}$ & $50^{\circ} \mathrm{C}$ \\
\hline 5 & 64 & 74 & 80 \\
\hline 15 & 74 & 81 & 95 \\
\hline 30 & 81 & 85 & 100 \\
\hline 60 & 85 & 91 & 0 \\
\hline 90 & 92 & 100 & 0 \\
\hline 120 & 95 & 0 & 0 \\
\hline Mean & $81.80 \%$ & $862 \%$ & $91.70 \%$ \\
\hline
\end{tabular}

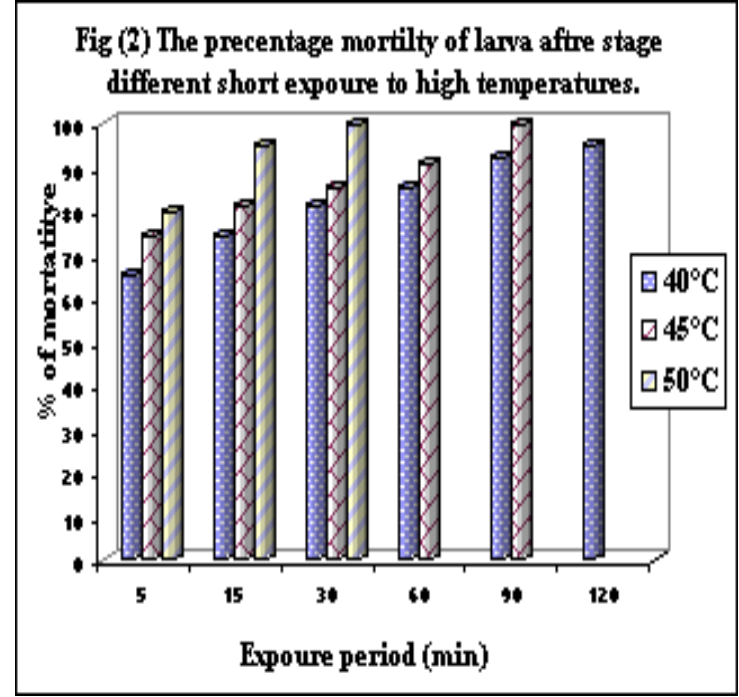

The effect of the high temperature and intervals exposure on mean potopnymph mortality percentage are presented in Table (3). The obtained results showed that the highest mean percentages 88.7, 82.2 \&71.3\% followed discerningly and represented high significant by of temperatures $50,45 \& 40^{\circ} \mathrm{C}$. Also it recorded 100 with short exposure $60 \mathrm{~min} .45^{\circ} \mathrm{C}$ recorded $100 \%$ reduction at $90 \% \mathrm{~min}$, while degree $40^{\circ} \mathrm{C}$ recorded 90 at $120 \mathrm{~min}$ The interaction effect of high temperatures with short exposure periods was highly significant. 
Table 3. Percentage of mortality for stage Tyrophagus putrescentiae protonymph after different shock exposure at high temperatures.

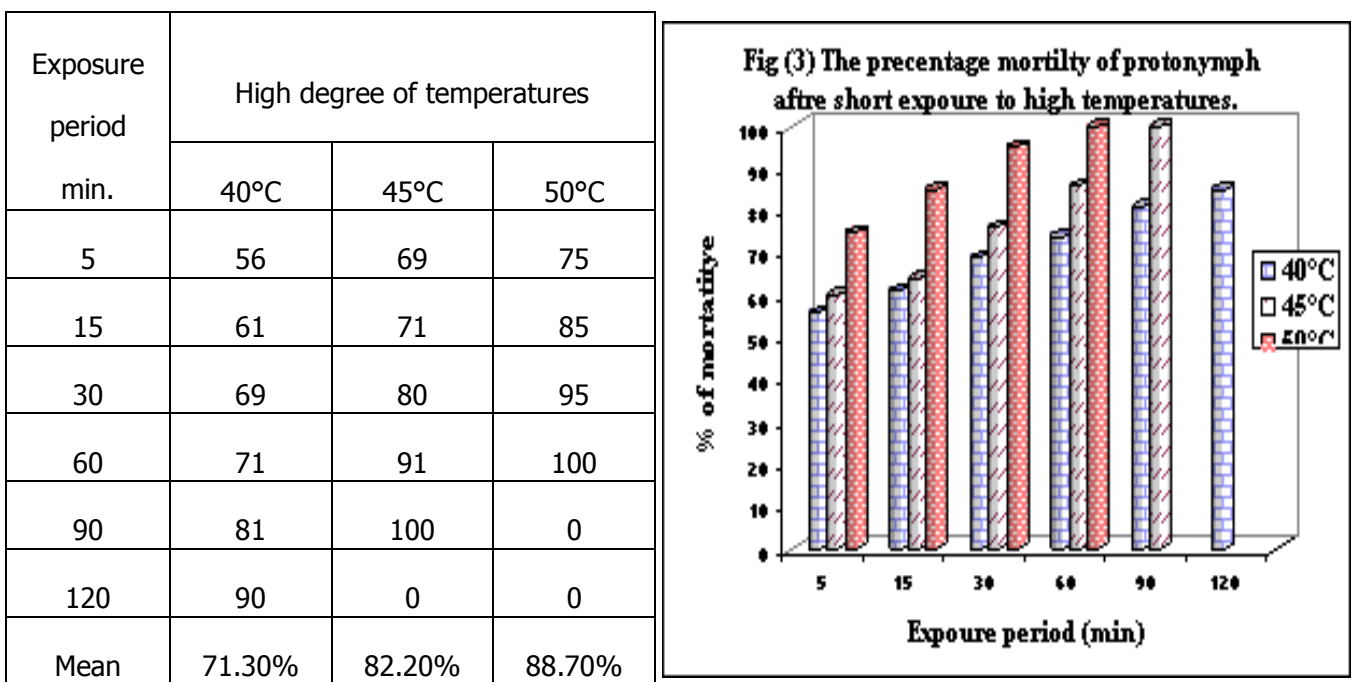

Data in Table (4) indicated that the mean dueotonymph mortality percentage after shock exposure $(5,15,30,60,90 \& 120 \mathrm{~min}$.) at high temperatures (40, 45, $50^{\circ} \mathrm{C}$ ) significantly increased with increasing the degree of temperature. Mean percentage dueotonymph of mortality percentage egg was represented by $86.5 \%$ at the highest degree $50^{\circ} \mathrm{C}$. It also recorded 100 with short exposure $60 \mathrm{~min}$, then significantly and gradually decreased for degree $45^{\circ} \mathrm{C}$ lasted $80.5 \%$ and recorded reduction 100 at $60 \mathrm{~min}$. while degree $40^{\circ} \mathrm{C}$ gave $70.3 \%$, and $85 \%$ at $120 \mathrm{~min}$. The interaction effect of high temperatures with short exposure period was highly significant.

Table 4. Percentage mortality of stage T. putrescentiae deuotonymph after different shock exposure at high temperatures.

\begin{tabular}{|c|c|c|c|}
\hline \multirow{2}{*}{$\begin{array}{c}\text { Exposure } \\
\text { period } \\
\text { min. }\end{array}$} & \multicolumn{3}{|c|}{ High degree of temperatures } \\
\cline { 2 - 4 } & $40^{\circ} \mathrm{C}$ & $45^{\circ} \mathrm{C}$ & $50^{\circ} \mathrm{C}$ \\
\hline 5 & 55 & 65 & 71 \\
\hline 15 & 61 & 71 & 82 \\
\hline 30 & 65 & 86 & 93 \\
\hline 60 & 75 & 100 & 100 \\
\hline 90 & 81 & 0 & 0 \\
\hline 120 & 85 & 0 & 0 \\
\hline Mean & $70.30 \%$ & $80.50 \%$ & $86.50 \%$ \\
\hline
\end{tabular}

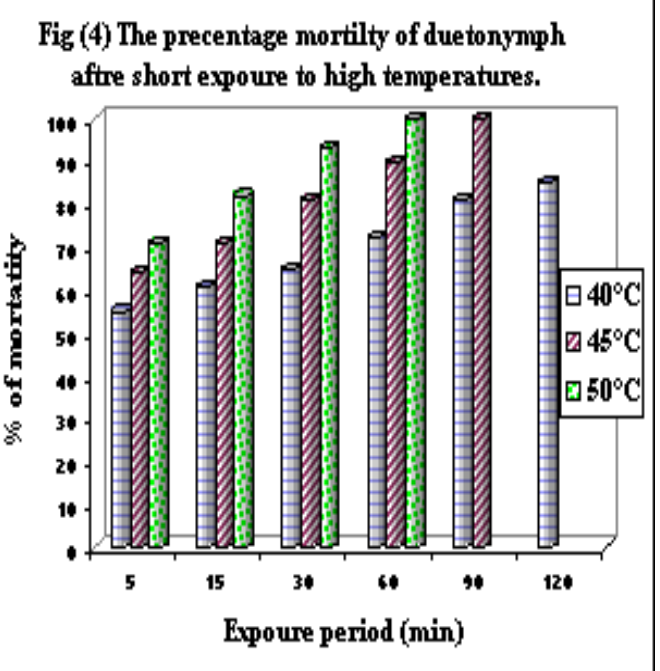


Due to adverse nature of some established methods there is a constant search for new means of controlling mites in stored grains. Our heat studies showed that mortality percentage increased with increasing exposure and temperature degrease for all stages (egg, larva, protonymph and deutonymph, $40,45 \& 50^{\circ} \mathrm{C}$ ). This conclusion agree with the conclusion returning to spider mite as Crooker (1985) reported that the upper lethal limit for immatures may be $38-40^{\circ} \mathrm{C}$, but much variation can be expected depending on species, life stage, humidity and duration of exposure. therefore, Tanigoshi et al. (1975) observed high mortality rates in active immature stages of Tetranchus macdanieli at $38^{\circ} \mathrm{C}$. The rate of all immature stage reaching adult stage decreased with increasing period and with increasing temperature treatment. This rate reached to $0 \%$ for all immature stages at $50^{\circ} \mathrm{C}$ for $120 \mathrm{~min}$. This conclusion agree with the conclusion of Okasha (1986c) that growth and development are not initiated at high temperature, but on the contrary, these processes start after transfer to normal temperature. He found that after transfer of the nymphs to normal temperature $\left(28^{\circ} \mathrm{C}\right)$, molting is delayed. The duration of the delay is directly proportional to the period exposure to high temperature. He explained that the brain hormone is not secreted during the period of exposure to high temperatures, so that molting ceases at high temperatures.

\section{REFERENCES}

1. Bligh, J., J. E. Cloudsley Thomson and A. G. MacDonald. 1976. Environmental physiology of animals. Blackwell Scientific Publication, Oxford.

2. Champ, B. R., C. E. Dyte. 1976. Report of FAO global survey of pesticide susceptibility of stored grain pests, FAO Plant Protection and Protection series no 5 (food and agriculture organization of the United Nations, Rome)

3. Chen, C.P., R. E. Lece and D. L. Denling 1991. Cold shock and heat shock: comparison of protection generated by brief pretreatment at less sever temperatures. Phys Entomol. 16: 19-26.

4. Crooker, A. 1985. Embryonic and juvenile development PP 149-163, in Helle, W. and M. W. Sabelis (Ed) spider mites. Their biology, naturl enemies and control Vol. 1A. Nork, Elsevier.

5. Fields, P. G. 1992 The control of stored -product insects and mites with extreme temperatures Journal of stored Products Research 28, 89-118.

6. Johnson, J. A., S. Wang and J. Tang. 2003. thermal death kinetics of fifth instars Plodia interpuncteella (Lepidoptera: Pyralidae). Journal of Economic Entomology 96, 519-524. 
7. Ikediala, J. N., J. Tang and T. Wig. 2000. A heating block system for studying thermal death kinetics of insect pets. Transaction of the American Society of Agricultural. Engineers 43, 351-358

8. Kitch, LW., G. Ntoukam, R. E. Shade, J. L. Wolfson and L. L. Murdock. 1992. A solar heater for disinfesting stored cowpeas on subsistence farms. Journal of Stored Products Research 28 (4), 261-267.

9. Okasha, A.Y. K. 1986a. Effect of sub -lethal high temperature on an insect, Rhodniun prolixus (Stal.) Induction of delayed mounting and defect. J. Exp Biol. 48: $455-463$

10. Tanigoshi, L., S. C. Hoyt , R.W. Browne and J. A. Logan. 1975. Influence of temperature on population increase of Tewtranchus madanieli (Acarina: Tetranychdae). Ann. Entomol. Soci. Amer. 68: 972-978.

11. Waddell, B. C., V. M. Jones and D. B. Birtles. 1993. Comparative mortality responses of two species of mites following heat treatment. Proc. 46 "N.Z. Plant Protection Conf 1-5.

12. Wang, S., X. Yin, J. Tang, J. D. Hansen. 2004. Thermal resistance of different life stages of codling moth (Lepidoptera: Tortricidae) J. of Stored Product Research 40, 565- 574. 


\title{
Tyrophagus تاثير درجات الحرارة العالية على حياة اكاروس الحبوب المخزونة
} putrescentiea$$
\text { مريم عبد الرحمن السندى }
$$$$
\text { معهُ بحوث وقاية النبانات - مركز البحوث الزراعبة - دقى - جيزة }
$$

استخدمت الحـرارة العاليـة فـى مكافحـة بعض الافـات وخاصـة آفـات الحبوب والمـواد

المخزونـة ، بوجد ثلاث مناطق حرارية لاى كائن حى : المنطقة الحرارية الاولى هى درجـة

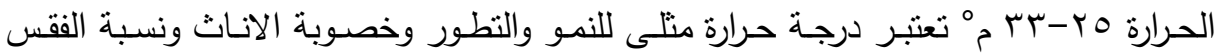

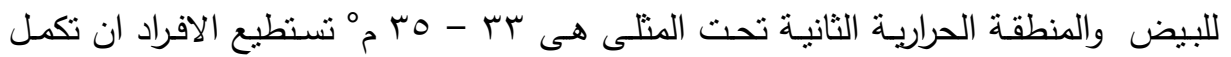

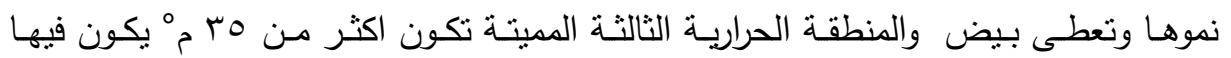

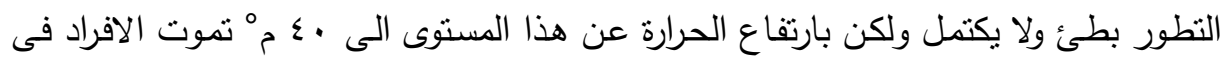

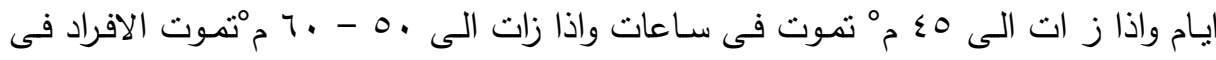
دقائق لذا فان الدراسـة استهدفت الى استخدام درجات الحرارة العالية للحد من اعداد الافة بتعريض هذة الاطوار المختلفة للحلم الحبوب T.putrescntiae عند درجة حرارة •ـ ،

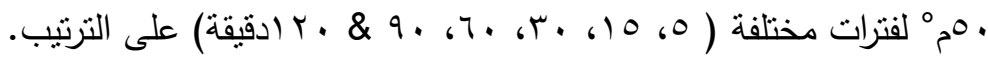

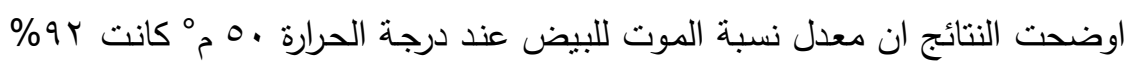

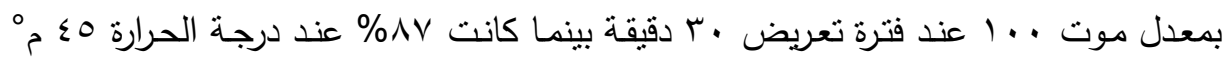

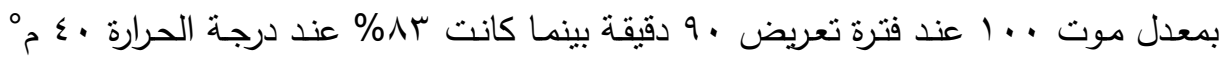
بمعدل موت 90 عند فترة تعريض • r ا دقيقة على الترتيب. حيث اظهرت النتائج ان معدل

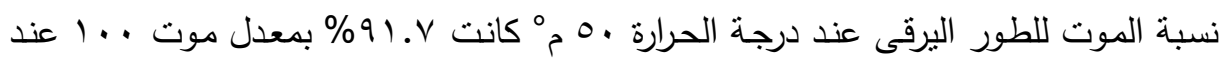

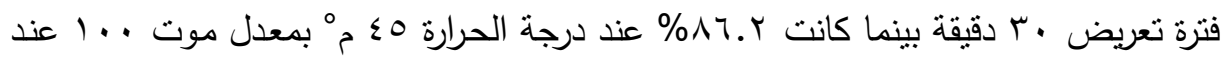

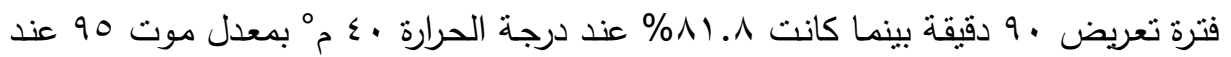

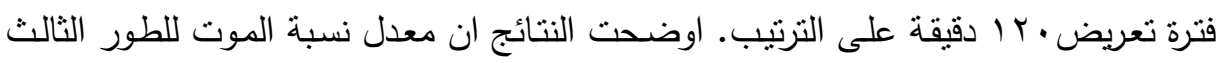

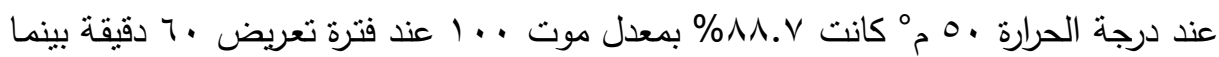

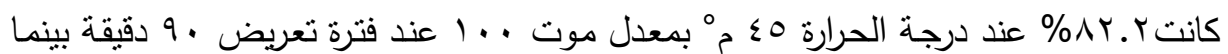

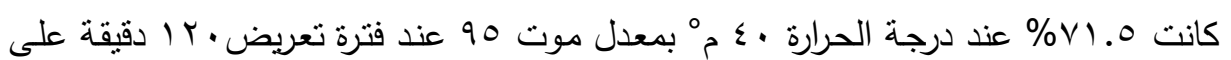

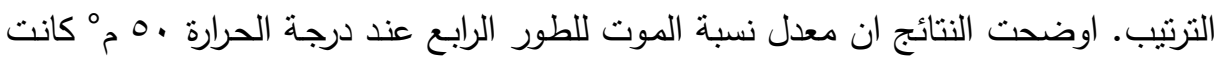

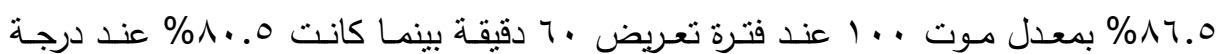

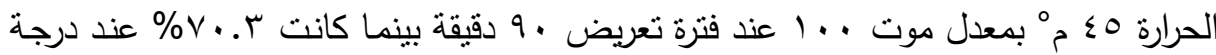

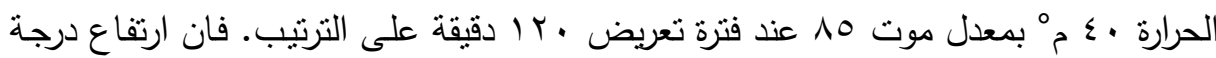

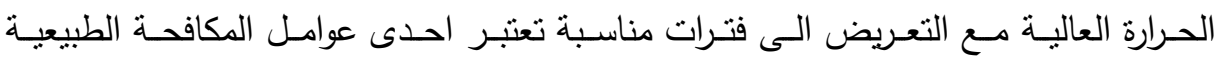
للاكاروسات المواد والحبوب المخزونة. 